\title{
癌免疫療法の開発：メラノーマ研究からのレッスン
}

河上裕

\section{Development of immunotherapy for cancer: Lessons from melanoma research}

\author{
Yutaka KAWAKAMI \\ Division of Cellular Signaling, Institute for Advanced Medical Research, Keio University School of Medicine
}

(Received March 29, 2004)

\begin{abstract}
summary
Identification of human melanoma antigens by various molecular biological and immunological techniques and evaluation of tumor reactive $\mathrm{T}$ cells in patients with the identified tumor antigen and HLA tetramer technology, not only provided us more profound understanding of anti-tumor immune responses in human, but also led to reveal basic problems in each step towards immunological tumor rejection, including systemic suppressive mechanisms such as regulatory $\mathrm{T}$ cell induction and local inhibitory environment in tumors. Based on these results obtained from the basic and clinical researches, various improvements have been applied for immunotherapy, including active immunization with modified antigenic peptides and recombinant virus, $\mathrm{T}$ cell adoptive transfer with lymphodepletive pretreatment, and administration of anti-CTLA-4 Ab, although further improvement is necessary. The translational research performed on melanoma, would facilitate development of immunotherapy for other cancers.
\end{abstract}

Key words_- Tumor antigens; HLA tetramer; Immunotherapy; Melanoma; Cancer

抄録

メラノーマにおいては, 網羅的遺伝子解析やDNA クローニングなどの分子生物学的および免疫学的手法を用い た $\mathrm{T}$ 細胞認識腫瘍抗原の同定が進み, 同定した腫瘍抗原ペプチドで作製した HLA テトラマーを用いて，患者にお ける抗腫瘍 $\mathrm{T}$ 細胞の生体内動態の詳細な解析が行われ，ヒトにおける抗腫瘍免疫応答の解明だけでなく，制御性 $\mathrm{T}$ 細胞誘導などの全身性免疫抑制機構や腫瘍局所での阻害因子などの免疫学的腫瘍拒絶における各ステップの問題点 を細胞・分子レベルで明らかにしてきた。このような臨床・基礎研究成果をもとに, 改変腫瘍抗原ぺプチド，組み 換えウイルス，樹状細胞などを用いた能動免疫法，抗 CTLA-4 抗体の併用投与，リンパ球減少性前処置後の T 細 胞養子免疫療法など, 様々な免疫療法の改良が進められている. メラノーマに対するトランスレーショナルスタデ ィの成果は, 他の癌種の免疫療法の開発に役立つと思われる.

\section{I. はじめに}

最近の動物実験やヒト腫瘍抗原の解析結果は癌細 胞に対する免疫監視 (immunosurveillance) の存在 を示唆したが, ヒトの癌は長い年月を経て免疫防御 をすり抜けて (tumor escape) 増殖しており, 臨床 でみられる癌を免疫で排除するのは簡単でない。し かし，メラノーマでは免疫学的排除が確認されてお り，癌細胞に質的・量的に正常細胞とは異なる分子 発現があり, 弱くても免疫原性があるならば, 強力 な免疫操作による腫瘍排除も不可能ではない。過

慶應義塾大学医学部 先端医科学研究所 細胞情報研 究部門
去, 非特異的免疫賦活剂を初めとして, 様々な免疫 療法が評価されたが, 統計学的には十分な抗腫瘍効 果が認められない場合が多く, 効果が認められた例 でもその機序は不明であり, 科学的な改良が困難で あった. しかし, 近年の腫瘍免疫学の進歩, 特に $\mathrm{T}$ 細胞認識腫瘍抗原の同定と HLA テトラマー技術の 開発により, 抗腫瘍 $\mathrm{T}$ 細胞の患者生体内動態の測 定が可能になり, 今までブラックボックスであった 癌の免疫学的拒絶にいたる各段階の問題点が解明さ れつつあり, 現在, 様々な改良が試みられている. 免疫療法の開発においては，1）自己癌細胞に対す る免疫応答の証明と担当免疫細胞の同定，2）腫瘍 抗原の同定, 3) 腫瘍エスケープ機構の解明と克服 法の開発，4）強力な免疫制御法の開発，5）臨床試 
験による評価などの基本課題を解決していく必要が ある. そのためには, 動物腫瘍モデル実験を参考に しながら, 臨床試験施行とその後の基礎研究に基づ いた更なる臨床試験というサイクル的な translational study が重要である，本稿では，我々が免疫 療法における第一の対象として Translational study を実践してきたメラノーマに対する免疫応答解析と 免疫療法開発の歴史と現状を紹介するが，より主要 な癌種の免疫療法開発に役立てばよいと思う.

\section{II. 腫瘍拒絶における $\mathbf{T}$ 細胞の重要性の確認}

米国国立癌研究所（NCI）外科では，精製 IL2 の 抗腫瘍効果をマウス腫瘍モデルで証明したが，大量 の組み換え IL2 が使用可能となり, 各種癌に対し て IL2 投与の臨床試験を施行し, 腎癌とメラノー マで明らかな抗腫瘍効果を確認した。 進行メラノー マ患者に対しては約 15\%(27/182) の奏効率が認 められ，CR 例では長期生存が認められるのが特徵 であった．次に，IL2 活性化リンパ球（LAK）を用 いた養子免疫療法の臨床試験を施行し，初期の成績 では IL2 単独投与よりも高い効果が得られたが, 再度の臨床試験では十分な有意差が認められず，臨 床試験結果解釈の難しさを感じる結果となつた ${ }^{1)}$.

しかし，臨床試験に参加した患者検体を用いた基礎 研究はその後のメラノーマの免疫療法開発に重要な 知見を生んだ。生検腫瘍組織の免疫組織学的検索に より，退縮腫瘍内には $\mathrm{T}$ 細胞の強い浸潤が認めら れ，培養した腫瘍浸潤リンパ球（TIL）からは自家 腫瘍を認識する CD8+ 細胞傷害性 $\mathrm{T}$ 細胞 (CTL) と $\mathrm{CD} 4+\mathrm{T}$ 細胞が検出され, 腫瘍拒絶には腫瘍反 応性 $\mathrm{T}$ 細胞が重要な役割を果たすことが示唆され $た^{2,3)}$. $\mathrm{T}$ 細胞の抗原特異性を検討したところ，自 己癌細胞だけに提示される固有抗原と他の患者癌細 胞にも提示される共通抗原を認識する場合があり, また共通抗原を認識する場合でも，メラノーマ細胞 だけ, メラノーマ細胞と正常色素細胞, 他の癌種も 等，多様な腫瘍抗原の存在が推定された．培養 TIL の養子免疫療法の臨床試験では 34\%（29/86）の奏 効率を認め, 投与 $\mathrm{T}$ 細胞の抗腫瘍効果が示され た。この際，投与 $\mathrm{T}$ 細胞の腫瘍内集積 ${ }^{111} \mathrm{In}$ 標識 試験), 自己癌細胞の認識傷害 $\left({ }^{51} \mathrm{Cr}\right.$ 遊離アッセ イ），比較的短期培養（4-6 週間）などが抗腫瘍効 果と相関することが認められた4).

\section{T 細胞が認識する腫瘍抗原の解析}

\section{1. $\mathbf{T}$ 細胞認識腫瘍抗原の同定}

メラノーマ反応性 $\mathrm{T}$ 細胞が認識する腫瘍抗原を 同定することが，生体内腫瘍拒絶を起こし得る免疫 応答の解明と効果的な免疫療法の開発につながる.

Boon らはマウス P815 腫瘍において，世界で初め て腫瘍反応性 $\mathrm{T}$ 細胞で癌細胞ゲノム DNA ライブ ラリーをスクリーニングする発現クローニング法に より $\mathrm{T}$ 細胞認識腫瘍抗原の単離に成功した。我々 は，患者に投与して腫瘍縮小が認められた培養 TIL を多数凍結保存していたので，その標的抗原を同定 することを試みた。その後 Boon らは末梢血リンパ 球から in vitro メラノーマ刺激により樹立したメラ ノーマ反応性 $\mathrm{T}$ 細胞を用いてヒトメラノーマ抗原 MAGE1 を単離した5). MAGE は脱メチル化により 様々な癌種に発現し，正常組織では精巣に発現する 分子で, 癌精巣抗原と呼ばれた。精巣では精粗細 胞，精母細胞など MHC クラス I 陰性細胞に発現す るので，正常細胞は $\mathrm{T}$ 細胞に認識されず，腫瘍特 異的共通抗原となり, 免疫療法の標的として魅力的 である。しかし，その免疫原性は強くなく，腫瘍に おける発現の heterogeneity が問題にされた.

\section{2. 組織特異的腫瘍抗原の解析}

我々は養子免疫療法にて腫瘍縮小が認められ, 免 疫学的解析により頻度の高い HLA-A2 拘束性に共 通抗原を認識することが確認された $\mathrm{T}$ 細胞を用い て，独自の cDNA クローニング法により，gp100 と MART1 抗原を単離した ${ }^{6 \sim 8)}$ 。これらは色素細胞 特異的蛋白であり， $\mathrm{T}$ 細胞エピトープを解析すると HLA-A2 結合に重要な $\mathrm{N}$ 末端から 2 番目あるいは $\mathrm{C}$ 末端が結合に最適なアミノ酸でなく, HLA 結合 親和性が比較的低いペプチドが多いことが判明し た ${ }^{9,10)}$ 。このために正常色素細胞や樹状細胞などの 専門的抗原提示細胞の表面に提示されにくい，比較 的 cryptic なエピトープである可能性が示唆された.

Romero らは健常人，メラノーマ患者末梢血，転移 リンパ節での MART1 特異的 CD $8+\mathrm{T}$ 細胞の頻度 と分化状態 (naïve, memory, effecter) を HLA テ トラマーで解析検討したが，健常人未梢血では抗原 未感作ナイーブ $\mathrm{T}$ 細胞だけが検出され，メラノー マ患者末梢血ではメモリー $\mathrm{T}$ 細胞も検出され た ${ }^{11)}$ 。転移リンパ節ではメモリー $\mathrm{T}$ 細胞，エフェ クター $\mathrm{T}$ 細胞が増加しており, 我々も確認したよ 
うに腫瘍内にもメモリー・エフェクター $\mathrm{T}$ 細胞が 集積している。したがって, 健常人ではこれら T 細胞は活性化も免疫寛容も起こらず ignorance の状 態であるが, メラノーマ患者では, メラノーマ細胞 増殖による抗原負荷, メラノーマ細胞上 HLA の増 加, 癌細胞メラノソーム蛋白輸送異常に伴う蛋白分 解上昇による抗原ペプチドの過剩産生, その上, IL2 投与や in vitro 培養などの免疫操作により, 通 常では silent な $\mathrm{T}$ 細胞が活性化され，一旦活性化さ れると癌細胞傷害やサイトカイン産生を介した炎症 反応などを引き起こしてメラノーマ退縮を起こす可 能性が示された。 cryptic といっても, IL2 関連免 疫療法施行後に色素細胞傷害による部分的な皮膚白 斑が出現することがあり, 腫瘍縮小とに正の相関が 認められている12)。これらの結果は, メラノーマで は色素細胞に対する免疫応答が起こりやすく, 色素 細胞蛋白特異的 $\mathrm{T}$ 細胞がメラノーマ拒絶と色素細 胞傷害に関与することを示している13).

\section{3. 癌細胞遺伝子異常に由来する変異抗原の解析}

次に, Boon ら, Wolfel ら, 我々は癌細胞に生じ た突然変異のために産生されたアミノ酸変異をもつ ペプチドが自己腫瘍特異的抗原になることを証明し た ${ }^{14,15)}$. 歴史的には, 癌細胞は正常細胞と異なる異 物として認識されるのではないかと期待されていた が，その分子基盤が証明された。我々が単離した $\beta$-catenin やMART2 (mutated Skinny Hedgehog acyltransferase）では, 突然変異により産生される 変異ペプチドが患者 HLA に結合可能になり自己腫 瘍特異的 $\mathrm{T}$ 細胞を誘導している。単離した変異 $\beta$-catenin では重要なリン酸化部位に変異があり, そのために分解が妨げられて Wnt シグナルが活性 化されており, 癌細胞形成への関与が見つかつた ${ }^{16)}$.

CDK4 などの他の変異抗原分子でも同様なことが報 告され, 腫瘍抗原の同定が癌細胞生物学研究に貢献 している17).

腫瘍特異的変異ペプチド抗原が単離される頻度 は, 組織特異的抗原由来の自己ペプチド抗原に比べ て低い。一つの可能性として, 高免疫原性変異ペプ チドを提示した癌細胞は, $\mathrm{CD} 8+\mathrm{T}$ 細胞による免 疫監視機構により臨床的に診断される前に排除され た可能性がある。興味深いことに, CD4+ T 細胞 の場合むしろ自己腫瘍特異的ペプチドを認識する T 細胞が高率に検出されており, CD4+ T 細胞反応 だけでは MHC クラス II 陰性固形癌を拒絶できな
いことを示しているのかもしれない. CD8+ T 細 胞認識抗原の場合, 変異ペプチドの免疫原性がそれ ほど高くないために $\mathrm{T}$ 細胞が誘導されても拒絶さ れず，また癌細胞の増殖・生存に関わる分子のため に抗原消失が起こらなかった場合, 変異抗原を発現 する癌細胞とそれに対する $\mathrm{T}$ 細胞のペアーを得る ことができ，変異抗原が同定できた可能性がある. 変異ペプチド特異的 $\mathrm{T}$ 細胞が検出できた患者では 治療後の予後が良い場合が多く, HLA テトラマー を用いて患者体内では変異抗原特異的 $\mathrm{T}$ 細胞の頻 度が高い例が報告されており, 癌細胞の増殖抑制に 関与した可能性が示されている18)。このような患者 では免疫療法の効果が期待できると考えられる. 個 々の患者の癌細胞遺伝子変異が究極の免疫療法の効 果予測指標となる可能性がある. 癌細胞には多くの 遺伝子異常が蓄積し変異ペプチドも多数産生されて いるが，全てが抗原プロセスされ患者 HLA により 癌細胞上に提示されるとは限らない. また, 自己腫 瘍特異的ペプチドを個々の患者ごとに同定して治療 に用いることは困難で, 共通変異でない限り多数の 患者に使用できない. しかし, 変異ペプチド特異的 $\mathrm{T}$ 細胞をもつ患者は予後が良い場合が多いので, 再 発時に同定抗原を治療に使用できる場合がある. 腫 瘍抗原の同定をせずに固有抗原に対する免疫誘導を 起こす方法として, 共通腫瘍抗原の免疫により固有 抗原に対する抗原スプレッディング (Ag spreading) を期待する方法や様々な自己腫瘍産物での免疫が考 えられている. 共通抗原であっても, 癌細胞での発 現量や, HLA タイプを含めた患者の免疫応答能に 規定されて個々の腫瘍抗原の免疫原性が異なること が判明しており, 免疫療法では他の治療法以上に個 別化医療が重要になる.

$\mathrm{T}$ 細胞エピトープの同定により, 様々な $\mathrm{T}$ 細胞 エピトープ形成機構が明らかになった ${ }^{19)}$ (表 1). 上記の cryptic エピトープ, 変異ペプチド以外に, 本来の機能蛋白とは異なる ORF にコードされるぺ プチドや不完全スプライシングにより残つたイント ロンによりコードされるペプチドが癌細胞で産生さ れて腫瘍反応性 $\mathrm{T}$ 細胞を誘導すること, 蛋白翻訳 後修飾により形成されるエピトープが存在すること など, $\mathrm{T}$ 細胞による癌細胞認識の分子基盤が明らか になった. HPLC と質量分析器を駆使した癌細胞 HLA 結合ペプチドの直接単離同定は, 実際に癌細 胞上に提示されている腫瘍抗原ペプチドの確認だけ でなく, エピトープの蛋白翻訳後修飾の解析に重要 
表 1 メラノーマ $\mathrm{T}$ 細胞エピトープ形成機序

\begin{tabular}{ll}
\hline \hline \multicolumn{1}{c}{ 機 } & \multicolumn{1}{c}{ 序 } \\
\hline 1. 機能蛋白由来自己ペプチド & \multicolumn{1}{c}{ 原 例 } \\
a. 組織特異的蛋白 & Melanosomal proteins (e.g. MART1, gp100) \\
b. 癌精巣抗原 & MAGEs, NY-ESO-1, etc. \\
2. 遺伝子異常由来変異ペプチド & $\beta$-catenin, CDK4, MUM-1,-2,-3, MART-2 \\
3. Alternative ORF 翻訳由来ペプチド & TRP-1, NY-ESO-1 \\
4. イントロン由来ペプチド & \\
a. 不完全スプライシング & gp100, TRP-2, MUM-1 \\
b. Cryptic promoter 転写 & N-acetyl glucosaminyl transferase-V \\
6. 蛋白翻訳後修飾 & \\
a. Deamidation & tyrosinase \\
b. Cysteine oxidation & tyrosinase \\
7. 免疫プロテアソームによる異なる抗原プロセス & MART1, gp100, MAGE1 \\
\hline
\end{tabular}

表 $2 \mathrm{~T}$ 細胞認識腫瘍抗原の同定法

A. 腫瘍反応性 $\mathrm{T}$ 細胞が樹立できる場合

1. 腫瘍抗原候補認識の検討

2. 癌細胞上 $\mathrm{MHC}$ 結合ペプチドの抽出・分離と質量分析器による同定

3. 腫瘍抗原精製と質量分析器による同定

4. cDNA 発現クローニング法による腫瘍抗原遺伝子単離
a. HLA 導入 COS・ 293 細胞システム
b. レトロウイルス cDNA ライブラリー・自己抗原提示細胞システム
c. MHC クラス II 導入 293 細胞と Ii 鎖融合 cDNA ライブラリー使用

B. 腫瘍反応性 $\mathrm{T}$ 細胞が樹立できない場合

1. 腫瘍抗原候補分子の同定

a. 癌細胞に特異的・高発現される蛋白, 組織特異的蛋白（網羅的遺伝子シークエンス，CGH 法，SAGE 法，DNA チッ プ・マイクロアレイ, EST データベース, cDNA サブトラクション, RDA 法)

b. 癌患者血清・腫瘍内 B 細胞産生 IgG 抗体認識蛋白 (SEREX 法)

c. 癌遺伝子 - 癌抑制遺伝子産物, ウイルス蛋白などの腫瘍抗原候補分子

2. 腫瘍抗原候補蛋白に対する $\mathrm{T}$ 細胞誘導と癌細胞認識確認

a. T 細胞誘導システム

1) in vitro $\mathrm{T}$ 細胞誘導

2) HLA トランスジェニックマウスの免疫

b. 抗原提示刺激細胞作製

1） HLA ペプチド結合モチーフにより予想したペプチドの合成

2) 腫瘍抗原候補ペプチド・組換え蛋白感作や cDNA ・ RNA 導入抗原提示細胞

な役割を果たした ${ }^{20)}$.

\section{4. 新しい腫瘍抗原同定法}

メラノーマでは腫瘍反応性 $\mathrm{T}$ 細胞を用いて様々 な改良を経て確立された DNA 発現クローニング法 により代表的な腫瘍抗原カタログが作成された。 メ ラノーマ以外の癌種においては腫瘍反応性 $\mathrm{T}$ 細胞 を樹立するのは簡単ではないので，腫瘍抗原同定の ためには他の方法が必要となる（表 2). 我々はメ ラノーマを中心に以下の手法を試み, 多数の新規腫 瘍抗原の単離に成功している. 癌患者血清 $\mathrm{IgG}$ 抗 体を用いた cDNA 発現クローニング法 (SEREX) は，患者において $\mathrm{IgG}$ 抗体と同じ標的抗原に対す
る CD4+ヘルパー $\mathrm{T}$ 細胞が活性化されていると推 定されるので CD4+ $\mathrm{T}$ 細胞認識抗原の単離法とし て有用であるが, $\mathrm{CD} 8+\mathrm{T}$ 細胞認識抗原も単離で きることが判明し, 現在様々な改良が加えられて各 種癌抗原の単離に使用されている21). SEREX 法で は癌に対する免疫応答とは無関係な抗原も単離され るので，治療後に抗腫瘍免疫応答が起こつたと考え られる症例, 特に癌退縮が認められた患者血清や, ヒト腫瘍を免疫不全マウスに移植して腫瘍組織内の $\mathrm{B}$ 細胞が産生するヒト抗体が濃縮されたマウス血清 を用いたスクリーニングなどにより，有用な腫瘍抗 原の単離効率を上げる試みがなされている22)。ま た, 組織特異的抗原, 癌精巣抗原, 癌細胞高発現抗 
原などは，DNA チップ・マイクロアレイ，SAGE， $\mathrm{CGH}$ などの網羅的遺伝子解析法と近年充害しつつ ある遺伝子データベースを駆使して，まず候補分子 を体系的に同定し，次に，in vitro $\mathrm{T}$ 細胞誘導法や HLA トランスジェニックマウスを用いて T 細胞認 識抗原となることを証明する手法も使われている23).

\section{5. 免疫療法開発における腫瘍抗原同定の意義}

$\mathrm{T}$ 細胞認識エピトープの同定により, 患者におけ る生体内での抗腫瘍免疫応答が，DTH 皮内反応， in vitro $\mathrm{T}$ 細胞誘導, 限界希釈法, ELISPOT 法, HLA テトラマー法などを用いて，定量的・定性的 に測定することが可能になった ${ }^{24)}$ ，特に，同定腫瘍 抗原で作製した HLA テトラマーを用いることによ り, 生体内での抗腫瘍 $\mathrm{T}$ 細胞の分布, 頻度, 状態 を定量的，定性的に詳細に解析できるようになった ことは, 癌免疫研究および免疫療法開発におけるブ レークスルーである。腫瘍抗原の同定は腫瘍エス ケープ機序として腫瘍抗原消失の時期と頻度を正確 に把握することを可能にし，また HLA テトラマー 解析によりメラノーマ抗原特異的アナジーがあり得 ることがみつかった ${ }^{25)}$. 同定腫瘍抗原を用いること により, 免疫療法において適切な量の抗原を適切な 形で適切な場所にタイミングよく投与することが可 能になり，その上，宿命的に免疫原性が弱い七ト腫 瘍抗原の原因を分子レベルで明らかにして，様々な 方法により免疫原性を増強することにより免疫効率 を最大限に上げることも可能になった ${ }^{26,27)}$.

\section{IV. 同定腫瘍抗原を用いた能動免疫療法}

\section{1. 同定腫瘍抗原の使用}

免疫療法の標的としての腫瘍抗原は, 多くの患者 に使えるかという共通性, 腫瘍特異性, 免疫原性, 免疫抑制性, 腫瘍拒絶能, 抗原消失性, 癌細胞の増 殖生存への関与, 自己免疫などの副作用などの様々 な点から個々の特徵を考慮する. 理想的な腫瘍抗原 とは, 多くの患者の全ての癌細胞に選択的に高発現 し, 癌患者で免疫原性が強く, 癌細胞の増殖生存に 関わるために抗原消失が起こりにくいということに なるが，現実的に全ての条件を満たす腫瘍抗原がみ つかっているわけではない。同定腫瘍抗原はペプチ ド，蛋白，DNA，RNA，組み換えウイルスなどの 様々な形で使用できるが，それぞれ長所，短所があ り，現時点でどれが最適かはまだ不明である．どれ を使うにせよ宿命的な低免疫原性を改善するための 工夫が必要である. 免疫原性増強のために, サイト カインやアジュバント併用以外に， $\mathrm{T}$ 細胞エピトー プ改変による HLA・TCR 結合能増強，ヘルパーエ ピトープ・リーダー配列・HIV-TAT-PTD・hsp な どの結合, リポソーム, コレステロール多糖体修飾 などが試みられている（表 3,4）。

\section{2. ペプチド免疫の臨床試験}

ペプチド免疫の長所は，GMP 品質試薬の多量合 成が簡単なこと, 腫瘍抗原 $\mathrm{T}$ 細胞エピトープには 樹状細胞などの免疫プロテアソームでは適切にプロ

表 3 メラノーマに対する免疫療法の報告例

\begin{tabular}{|c|c|c|}
\hline 免 疫 療 法 & 研究者（施設） & 有効例 $(\mathrm{CR}+\mathrm{PR}) /$ 施行例 (奏効率) \\
\hline 大量 IL2 単独 & Rosenberg (NCI) & $27 / 182(15 \%)$ \\
\hline 培養 TIL 投与＋IL2 & Rosenberg (NCI) & $29 / 86(34 \%)$ \\
\hline 培養 TIL 投与 + IL2 + Cy $/$ Flu 前投与 & Rosenberg (NCI) & $6 / 13(46 \%)$ \\
\hline MAGE3 ペプチド & Marchant (Ludwig Inst.) & $5 / 25(20 \%)$ \\
\hline 高 MHC 親和性改変 gp100 ペプチド+IFA+IL2 & Rosenberg (NCI) & $13 / 31(42 \%)$ \\
\hline gp100 ペプチド $(\mathrm{CD} 4 / 8)+\mathrm{IFA}$ & Rosenberg (NCI) & $1 / 19(5 \%)$ \\
\hline 改変 gp100 ペプチド+IFA+IL2+抗 CTLA4 抗体 & Rosenberg (NCI) & $3 / 14(21 \%)$ \\
\hline 組換え MART-1 アデノウイルス + IL2 & Rosenberg (NCI) & $4 / 20(20 \%)$ \\
\hline 組換え gp100 フォウルポックスウイルス + IL2 & Rosenberg (NCI) & $6 / 12(50 \%)$ \\
\hline ペプチド・癌細胞溶解物感作 DC+KLH & Nestle（Zurich 大） & $5 / 16(31 \%)$ \\
\hline ペプチド $(\mathrm{CD} 4 / 8)$ 感作 DC+KLH & Schuler（Erlangen 大） & $1 / 16(6 \%)$ \\
\hline ペプチド感作 DC $(\mathrm{CD} 34+)+\mathrm{KLH}$ & Banchereau (Bayler) & $3 / 18(17 \%)$ \\
\hline DC 腫瘍内投与 & Triozzi（Alabama 大） & $0 / 7 \quad(0 \%)$ \\
\hline 腫瘍抽出 hsp & Parmiani (INT, Italy) & $2 / 28 \quad(7 \%)$ \\
\hline GM-CSF 導入自己癌細胞 & Dranoff (DanaFarberCancer Inst) & $1 / 21(5 \%)$ \\
\hline $\mathrm{HLA}-\mathrm{B} 7 \cdot \beta_{2} \mathrm{mg}$ 遺伝子腫瘍内導入 & Nabel（Michigan 大） & $3 / 11 \quad(27 \%)$ \\
\hline
\end{tabular}

IFA, incomplete Freunds adjuvant, $\beta_{2} \mathrm{mg}, \beta_{2}$-microglobulin, cy/Flu, cyclophosphamide/fludarabin 
表 $4 \mathrm{~T}$ 細胞応答を利用した能動免疫法

A. 同定腫瘍抗原を用いる方法

a. 腫瘍抗原ペプチド・蛋白の投与

1）ペプチド改変（MHC 高親和性，スーパーアゴニスト，多価結合，安定性・局所停滞性増強）

2）抗原修飾（ヘルパーエピトープ・リーダー配列・HIV-TAT-PTD・hsp 結合，リポソーム，コレステロール多糖体修 飾)

3）アジュバント・サイトカイン併用（フロインド不完全アジュバント, 合成アジュバント, IL2, IL12, IFN, GM-CSF）

4) $\mathrm{CD} 8+\mathrm{T}$ 細胞認識抗原と $\mathrm{CD} 4+\mathrm{T}$ 細胞認識抗原の併用

b. 腫瘍抗原蛋白・ペプチド感作，遺伝子導入樹状細胞の投与

（各種物質による CD40，TLR，サイトカイン受容体刺激による樹状細胞の成熟・活性化）

(IL1 $\beta$, TNF $\alpha$, IL6, PGE2, IFN $\alpha$, IFN $\gamma$, BCG-CWS, OK432, Imidazoquinolines, CpG モチーフなど)

(HIV-TAT-PTD)

c. 腫瘍抗原遺伝子組換えベクターの投与

1）プラスミド（非メチル化 $\mathrm{CpG}$ 配列）（筋注，遺伝子銃）

2) ウイルス（アデノウイルス，フォールポックスウイルス，ワクチニアウイルス）

3) 細菌 (BCG, リステリア, サルモネラ)

B. 腫瘍抗原の同定が必要ない方法

a. 高免疫原性修飾癌細胞による免疫

1） サイトカイン・ costimulatory 分子 ・ 外来抗原遺伝子導入自己癌細胞の投与（IL2, TNF $\alpha$, IL 12, IFN $\alpha$, IFNr, GM-CSF, IL4, CD80, HLA-B7)

2) ハプテン修飾癌細胞の投与 (DNP)

3）ウイルス感染による癌細胞修飾（HSV）

4) 癌細胞・樹状細胞融合細胞の投与

b. 癌細胞抽出抗原成分による免疫

1）ペプチド, 蛋白, RNA 感作樹状細胞の投与

2) ストレス蛋白の投与 (gp96, hsp70)

C. 免疫操作による抗腫瘍免疫増強

a. 非特異的免疫賦活剂, サイトカイン投与

b. 抗 CTLA4 抗体, 抗 CD25 抗体, 抗 GITR 投与

c. Th1 応答増強

セスされないものがあるが，その場合も使用できる ことである ${ }^{28)}$ 。短所として，多様な HLA に結合す るペプチドの同定が必要, 個々の癌に固有な変異ぺ プチドを同定して用いることは困難などである．我 々が単離した MART1 と gp100 は比較的免疫原性 が高く, 発現頻度の高い HLA-A2 に拘束される T 細胞エピトープを同定していたので, 合成ペプチド 免疫の臨床試験を最初に試みた ${ }^{29)}$. 不完全フロイン ドアジュバント（IFA）とともに皮下投与した結果， 確かな $\mathrm{T}$ 細胞エピトープでもペプチドによっては 生体内では免疫誘導を起こせない場合があり, 臨床 試験で個々のペプチドの免疫原性を確認することは 重要である. 免疫誘導が認められたペプチドでも限 界希釈法などで定量すると, ウイルスなどの外来抗 原に比べると免疫原性が低いことが判明した．免疫 増強法として, アジュバントやサイトカインの併用 が最初に実施された。 IFAの代わりに合成アジュ バントもテストされたが IFA より優れるという臨 床試験結果はでていない. 今後, TLR 刺激などの
観点から強力なアジュバント開発が期待される。サ イトカインでは IL2，GM-CSF，IL12 併用が試みら れ，Knuth らのペプチドとの併用試験では，GMCSF に免疫増強効果を認めたが， NCI でのペプチ ド・IFA 併用免疫においては，GM-CSF，IL12 と もに優れた免疫増強効果は認められなかった。高用 量 IL2 の併用では明らかな抗腫瘍増強効果が認め られたが，末梢血中の CTL 前駆細胞をむしろ低下 させた， $\mathrm{T}$ 細胞が腫瘍などの組織に遊走した可能性 もあるが，この機序はまだ解明されていない年.

MART1, gp100 エピトープでは, HLA 結合アン カーアミノ酸の置換により HLA 親和性が 10 倍高 い改変ペプチドを作製して IFA 併用免疫の臨床試 験を行ったところ, 免疫原性上昇が確認された. 改 変ペプチド単独投与では 11 例中 3 例が mixed response であったが, 高用量 IL2 併用では $42 \%$ (13/31) に臨床効果が認められ, 現在, 米国では抗 腫瘍効果確認と機序解明のための多施設臨床試験が 進行中である27). 改変ペプチドの問題は, 反復刺激 
により改変ペプチドを認識するが元のペプチドや癌 細胞を認識しない $\mathrm{T}$ 細胞が優位に増殖してしまう ことである ${ }^{311}$. そこで元のペプチドと改変ペプチド の同時免疫の臨床試験が東京大学医科学研究所にて 実施されているが十分な免疫誘導効果は検出されて いない。ペプチド免疫においては, 最小 $\mathrm{T}$ 細胞工 ピトープペプチドよりも $30 \mathrm{mer}$ 前後の長い合成ぺ プチドを用いた方が生体内で樹状細胞にゆっくりプ ロセスされて抗原提示細胞上の半減期が長くなり, $\mathrm{CD} 4+\mathrm{T}$ 細胞, $\mathrm{CD} 8+\mathrm{T}$ 細胞ともに免疫誘導性が よいとの報告もあるが臨床試験ではまだ十分に検討 されていない.

\section{3. 臨床試験における免疫モニタリング}

gp100 免疫の臨床試験で CTL 誘導, ELISPOT, HLA テトラマー法など種々の測定法を試したとこ ろ, ぞの方法も末梢血中の特異的 $\mathrm{T}$ 細胞頻度の増 加を検出できたが, それぞれの長所, 短所が確認さ れた。例えば，HLA テトラマーは FACS 解析によ るバックグラウンド, 低頻度 $\mathrm{T}$ 細胞の検出感度の 低さ，機能を反映していない，癌細胞を認識できな い低親和性 TCR-T 細胞も検出してしまうなどの問 題がある. 最近, CD8への結合性を消失させた HLA テトラマーを用いて高親和性 TCR-T 細胞と 低親和性 TCR-T 細胞を蛍光強度により区別できる 改良型 HLA テトラマーが作製されたので，今後, より機能に相関した測定ができる可能性がある32). 末梢血だけでなく腫瘍内での $\mathrm{T}$ 細胞の測定を行う ことが重要であるが, 退縮しつつある癌組織の生検 をできる機会は少なく，今まで検討された例では投 与ペプチド特異的 $\mathrm{T}$ 細胞が増加している例と検出 できない例が認められている，一部の例では，投与 ペプチドとは異なる腫瘍抗原特異的 $\mathrm{T}$ 細胞が検出 されており，末梢血でも認められている抗原スプレ ッディングによる抗腫瘍効果発現の可能性もあり, 共通腫瘍抗原免疫により腫瘍特異的抗原に対する $\mathrm{T}$ 細胞が誘導される可能もある.

Romero らはペプチド免疫前後での MART1 特異 的 CD8 $+\mathrm{T}$ 細胞の頻度と分化状態を HLA テトラ マーで解析検討したところ, 免疫後にはメモリー・・ エフェクター $\mathrm{T}$ 細胞の増加が認められたが, ウイ ルス感染後でみられるほどのエフェクター $\mathrm{T}$ 細胞 への分化が認められず，それが腫瘍拒絶まで至らな い原因の一つではないかと議論している33). また, 機序は不明であるが，腫瘍内浸潤 $\mathrm{T}$ 細胞はパーフ
オリン減少，サイトカイン産生低下などのために局 所で十分に機能できない可能性を指摘している. Boon らは MAGE3 ペプチド単独投与により腫瘍縮 小が認められたにもかかわらず，通常の ELISA 法 や Elispot 法では末梢血中にペプチド特異的 $\mathrm{T}$ 細胞 が検出できず，その機序が不明であったが，最近， 少ない細胞数をまいたウエルをぺプチドで刺激後に HLA テトラマーを用いて MAGE3 特異的 T 細胞を 検出したところ，特異的 $\mathrm{T}$ 細胞頻度が低いにもか かわらず，免疫後の増強と腫瘍縮小に相関が認めら れたので, マウス腫瘍モデルでの計算も参考にし て，低頻度ながら MAGE3 特異的 $\mathrm{T}$ 細胞誘導によ る抗腫瘍効果を推定しているが, 腫瘍内 $\mathrm{T}$ 細胞応 答は測定されていないのでその機序はまだ明らかで な( ${ }^{34)}$.

\section{CD4+ T 細胞認識エピトープ併用によるヘル} パー活性と制御性 $\mathbf{T}$ 細胞の作動

$\mathrm{CD} 4+\mathrm{T}$ 細胞は CD8 + $\mathrm{T}$ 細胞の誘導・活性化・ 維持やマクロファージなどのエフェクター活性化に 関わるだけでなく $\mathrm{CD} 8+\mathrm{T}$ 細胞の腫瘍集積にも関 与する可能性が報告されており, 適切な癌免疫誘導 のためには両抗原を併用することが望ましいと考え られている，そこで $\mathrm{CD} 4+\mathrm{T}$ 細胞認識 $\mathrm{gp} 100$ ペプ チドと CD8+ T 細胞認識 $\mathrm{gp} 100$ ペプチドとの併用 免疫の臨床試験が行われたが，期待に反してむしろ 免疫誘導が抑制された可能性が報告された ${ }^{35)}$ 。この 臨床試験においては in vitro $\mathrm{T}$ 細胞抑制機能をもつ $\mathrm{T}$ 細胞は検出されていないが，自己ペプチドに対す る CD4+ 制御性 T 細胞（T reg）が関与した可能性 がある. マウス腫瘍モデルにおいて SEREX 法で同 定した自己蛋白腫瘍抗原は DNA 免疫法による単独 免疫では CD4 + T reg を介して抗腫瘍免疫を抑制 するが, 免疫原性の高い $\mathrm{CD} 8+\mathrm{T}$ 細胞認識抗原と ともに免疫すると, むしろへルパー活性をもち抗腫 瘍免疫誘導を促進した ${ }^{36,37)}$. すなわち免疫療法のデ ザインが大変重要であり, 我々は SEREX 同定腫瘍 抗原をへルパー抗原として併用する計画をしている が， T reg を誘導しないために CD8+ T 細胞抗原ぺ プチドだけでなく, danger signal として KLH など の免疫原性が強い外来ヘルパー抗原や BCG-CWS や OK432 などの TLR 刺激物の併用を考えている.

$\mathrm{T}$ reg の癌免疫への関与については, マウス腫瘍 モデルにおいて，それを阻害する抗 CD25（IL2 $\alpha)$ 抗体, 抗 CTLA-4 抗体, 抗 GITR 抗体の投与によ 
り抗腫瘍 $\mathrm{T}$ 細胞誘導の増強が示されている ${ }^{38)}$. 腫 瘍浸潤 $\mathrm{T}$ 細胞から培養したヒトメラノーマ反応 性, 自己蛋白特異的 CD4 + T 細胞の中には FoxP3 と GITR 強陽性で in vitro $\mathrm{T}$ 細胞増殖抑制活性をも つ T reg が存在することも報告されている. 興味深 いことに腫瘍特異的変異ペプチドを認識するメラ ノーマ反応性 $\mathrm{T}$ 細胞には $\mathrm{T}$ reg がみつかっておらず,

T reg の自己ペプチドに対するレパートアを想像さ せる. メラノーマでは, ペプチド免疫に抗 CTLA4 抗体を併用する臨床試験が実施されたが, 投与ぺ プチドに対する免疫誘導増強効果は認めらなかった が，マウスと同様に自己免疫性腸炎などの一時的な 自己免疫反応が出現し, 自己免疫反応が認められた 患者に抗腫瘍効果 $(3 / 16,2 \mathrm{CR} 1 \mathrm{PR})$ が認められ, 癌患者での $\mathrm{T}$ reg の関与が示された ${ }^{39)}$.

\section{5. 樹状細胞を用いた免疫療法}

マウスモデルでは，ペプチド直接投与よりもペプ チド感作樹状細胞（DC）による免疫の方が抗腫瘍 効果が強いので臨床試験を試みたが, 最初の臨床試 験はマウス実験に基づき末梢血単核球付着細胞を GM-CSF と IL4 で培養誘導した未熟樹状細胞にぺ プチド感作して静注したためか免疫効果も抗腫瘍効 果も低かった ${ }^{40)}$. Nestle らは腫瘍抗原ぺプチド感作 DC を直接リンパ節に投与して約 $25 \%$ の奏効率を認 めた ${ }^{41)}$. その後, 多くの施設から末梢血 DC, 骨髄 細胞から誘導した DC などを用いた様々な臨床試験 が施行され，ほとんど効果の認められなかった例か ら $25 \%$ 前後の奏効率がみられる例が報告されてい る42). DC の最適な使用法が十分検討されていない ことが一つの問題であるが，体外培養 DC を用いる 場合, DC の種類, 培養誘導法, 抗原取り込み提示 法, 成熟活性化法, 病巣やリンパ節への遊走能の制 御，投与部位，投与スケジュールなど，今後の検討 が必要である. 最近 DC 機能の分子基盤が明らかに されつつあるが，DCの組織移動に関与するケモカ インによる DC の選択的動員, IFN, IL1 $\beta$, IL6, $\mathrm{TNF} \alpha$ などのサイトカインや微生物由来非メチル化 DNA (CpG モチーフ), BCG-CWS, OK432 などの TLR を刺激する微生物成分あるいは内因性 DC 成 熟化シグナルの一つとして活性化 CD4 + T 細胞が 発現する CD40L による DC の成熟活性化の制御な ぞが新たに試みられている. リンパ性 DC は血行性 移行により炎症リンパ節で $\mathrm{T}$ 細胞活性化を促進す ることが報告されているので，骨髄性とリンパ性両
DC を刺激するアジュバントの組み合わせにより， 強いアジュバント効果が期待できるかもしれない. アジュバントなどの DC 刺激分子を抗原投与部位に あらかじめ作用させておくと抗原免疫を促進できる ことも示されている. Fc 受容体や scavenger 受容体 などの DC 表面分子への抗原ターゲッティングによ る免疫誘導増強も動物実験で示されており今後の臨 床試験が期待される.

\section{6. 腫瘍抗原 DNA を用いた免疫療法}

マウスでは腫瘍抗原遺伝子組み換えウイルスによ る免疫が有効であり，アデノ・ワクチニア・フォウ ルポックスウイルスベクターを用いた MART1 と gp100 組み換えウイルスを直接投与する臨床試験が 施行されたが少数例で抗腫瘍効果が認められるにす ぎなかった ${ }^{43)}$. 臨床試験では抗ウイルス中和抗体に よる免疫誘導抑制が示唆された。しかし，最近，フ オウルポックスウイルスに $\mathrm{T}$ 細胞エピトープ部位 を組み込んだウイルス投与例では IL2 投与後に高 率に抗腫瘍勃果が認められており, 症例数増加によ る抗腫瘍効果の確認が期待されている44)。また， 2 種類の改変 gp100 ペプチドを産生する全長 cDNA 組み換えプラスミド DNA を筋注する DNA 免疫法 の臨床試験が施行されたが免疫効果も抗腫瘍効果も 弱かった ${ }^{45)}$. MART1 や gp100 の HLA-A2 拘束性 エピトープは抗原プロセスが必要となる全長 cDNA を用いた免疫法では樹状細胞の免疫プロテ アソームでは適切にプロセスされず $\mathrm{T}$ 細胞誘導が 起こらなかった可能性もある27).

\section{V. 同定腫瘍抗原に対する受動免疫療法}

培養腫瘍浸潤 $\mathrm{T}$ 細胞を用いた養子免疫療法では 抗腫瘍効果が認められていたが，腫瘍抗原の同定に より末梢血から腫瘍反応性 $\mathrm{T}$ 細胞を比較的簡単に 誘導できるようになったので, gp100 ペプチドで末 梢血リンパ球を刺激して誘導した $\mathrm{T}$ 細胞，特に高 親和性 $\mathrm{T}$ 細胞受容体をもつ $\mathrm{T}$ 細胞クローンを選択 培養して投与する臨床試験が施行されたが抗腫瘍効 果はあまり認められなかった ${ }^{46}$. 理由の一つとして 長期培養した $\mathrm{T}$ 細胞の生体内での増殖低下の問題 が考えられた。また，投与された $\mathrm{T}$ 細胞は末梢血 中から早期に消失していくことが問題であったが, 最近, $\mathrm{T}$ 細胞を投与する前にリンパ球減少・免疫抑 制作用をもち骨髄非破壊的同種造血幹細胞移植の 前処置に使用されている Cyclophosphamide と 
表 $5 \mathrm{~T}$ 細胞を利用した受動免疫法

A. 同定腫瘍抗原を用いる方法

a. 同定腫瘍抗原ペプチド・蛋白感作, DNA 導入抗原提示細胞を用いた in vitro 抗腫瘍 $\mathrm{T}$ 細胞誘導

B. 同定腫瘍抗原を用いない方法

a. 腫瘍浸潤リンパ球からの in vitro $\mathrm{T}$ 細胞培養

b. 末梢血リンパ球の癌細胞, 癌細胞成分感作抗原提示細胞による in vitro $\mathrm{T}$ 細胞誘導

C. 抗腫瘍免疫増強操作
a. IL2 投与（低用量，高用量）
b. リンパ球減少・免疫抑制性前処置 (Cyclophosphamide, Fludarabine)
c. その他（改変腫瘍抗原免疫など）

Fludarabine の投与を行うと, 投与 $\mathrm{T}$ 細胞が生体内 で高率に増殖維持されることが判明した ${ }^{47)}$ (表 5).

MART1 特異的 T 細胞投与後, HLA テトラマーや 特異的 $\mathrm{TCR}-\mathrm{V} \beta$ 抗体用いて, 投与 $\mathrm{T}$ 細胞の生体内 動態を追跡したところ，100日以上も末梢血中 CD8 $+\mathrm{T}$ 細胞の $75 \%$ が投与した MART1 特異的 $\mathrm{T}$ 細胞 に占められ， $\mathrm{T}$ 細胞は腫瘍内に浸潤して IFN- $\gamma$ や $\mathrm{TNF}-\alpha$ などのサイトカイン産生を介して癌細胞に HLA クラス I, クラス II を発現させ高率に（46\% (6/13)）腫瘍を退縮させた。この臨床試験は単に抗 腫瘍効果の改善を示しただけでなく, 今まで直接的 証拠の少なかった MART1 自己ペプチド特異的 T 細胞による腫瘍拒絶と自己免疫反応をほぼ証明し た.この驚異的な $\mathrm{T}$ 細胞の生体内維持増殖の原因 として前処置による投与 $\mathrm{T}$ 細胞の増殖を抑える $\mathrm{T}$ reg などの免疫反応の抑制, リンパ球が減少するこ とによりスペースができ IL15 や IL7 の産生も関与 した homeostatic proliferation が起こつた可能性が 考えられている. gp100 特異的 TCR トランスジェ ニックマウスと各種免疫不全マウスやノックアウト マウスを用いたマウス腫瘍モデルでの解析では, リ ンパ球減少性処置による CD4 + FoxP3 + T reg の 抑制とIL15 も関与する homeostatic proliferation の作動が示唆されている48). このマウスモデルで巨 大腫瘍を拒絶できる抗腫瘍効果を惹起するための条 件として, 活性化抗腫瘍 $\mathrm{T}$ 細胞の投与, 改変腫瘍 抗原による免疫, IL2 投与の 3 者が必要であること が示されており, 今後, 臨床応用が期待される. 本 臨床試験では腫瘍反応性 CD4+ T 細胞の存在が抗 腫瘍効果を増強した可能性も指摘されている.

\section{VI. 腫瘍抗原を同定せずに行う免疫療法}

自己腫瘍特異的な抗原に対する免疫誘導のため に, 修飾癌細胞や自己腫瘍抽出成分を用いる免疫療 法, あるいは腫瘍内に免疫増強操作を行う免疫療法
も試みられている。これらは多種類の自己腫瘍特異 的抗原に対して免疫できる可能性はあるが, 個々の 抗原量は非常に少ないので十分な免疫誘導効率が得 られるかどうかは問題である. 現時点で, 各種遺伝 子導入修飾癌細胞, ペプチド, 蛋白, RNA, hsp な ぞの癌細胞抽出成分を用いた臨床試験の抗腫瘍効果 はそれほど高くない. これらの臨床試験における免 疫モニタリングは難しい. Nestle らはメラノーマ自 己腫瘍融解物感作 DC 投与で約 $25 \%$ の奏効率を認 めたが40), 我々も共同で東京大学医科学研究所で実 施した自己腫瘍細胞凍結融解物感作 DC を $\mathrm{TNF} \alpha$ で成熟化後に皮内皮下投与し低用量 IL2 を併用す る臨床試験では, 10 人中 2 人の複数転移巣に広範 な中心性壊死を起こす腫瘍縮小が認められたが, 通 常の免疫学的腫瘍拒絶とは異なり, 機序不明な急速 な血流遮断による腫瘍壊死が推定された ${ }^{49)}$. Dranoff らは GM-CSF 遺伝子導入自己メラノーマ 細胞による免疫, Parmiani らは自己メラノーマか ら抽出した gp96-hsp による免疫の臨床試験を施行 し, 腫瘍内での免疫反応誘導と一部の患者で腫瘍縮 小を認めたが，強い抗腫瘍効果は得られていな (50,51). 自己腫瘍内への免疫操作による免疫療法と して未熟 DC 腫瘍内投与が行われたが，投与腫瘍と 近傍の転移巣の縮小が認められたものの遠隔転移巣 の縮小は認められなかつた52). 我々は未熟 DC を投 与するだけでなく腫瘍抗原の取り込みを促進させる ための凍結融解などの癌細胞にアポトーシスやネク ローシスを引き起こす腫瘍前処置と, 投与した未熟 $\mathrm{DC}$ を成熟させてリンパ節へ移動させ $\mathrm{T}$ 細胞を感作 するために，BCG-CWS や OK432 などの TLR 刺 激物や CD40L + 活性化 CD4 + T 細胞を誘導する KLH などの強免疫原性外来抗原の併用を行う免疫 療法をマウスモデルで開発し, メラノーマの臨床試 験を計画している. 


\section{VII. 癌細胞の免疫系からのエスケープの実体}

腫瘍抗原の同定により癌細胞における腫瘍抗原 抗原プロセスに関わる分子群の異常, 抗原特異的 $\mathrm{T}$ 細胞の消失や不活化などが患者においても検討可能 になった．今までに様々な腫瘍エスケープ機構が検 討されているが, 今後, 個々の患者でぞのような機 構が働いているかを考慮して適切な克服法を実施す ることが免疫療法の改良に重要な課題である（表 6).メラノーマにおいては, MART1 や gp100 腫瘍 抗原や HLA の消失が 5-25\%の転移巣で検出され 免疫療法後の患者に抗原消失転移巣が選択的に増殖 することが確認された ${ }^{53)}$. Tyrosinase 抗原特異的ア ナジーの可能性を示す症例も報告されている ${ }^{25)}$. ま た，上記のように，腫瘍組織内に腫瘍抗原特異的 $\mathrm{T}$ 細胞がある程度集積しているにも関わらず，サイト カイン産生能や癌細胞傷害能の低下により癌細胞を 拒絶できない可能性が示されており, 能動免度法に よる全身性の免疫増強だけでは腫瘍拒絶を起こすこ とは簡単ではないことを示している. 改変 gp100 ペプチド免疫や gp100 組み換えフォウルポックス ウイルス免疫においても高用量 IL2 の併用で初め て抗腫瘍効果が上がっており, IL2 が腫瘍血管障害 や多様なサイトカイン産生を介して腫瘍組織内の環 境を変化させて抗腫瘍効果を高めた可能性があ る 26,42$)$. 活性化抗腫瘍 $\mathrm{T}$ 細胞を用いた受動免疫法 は腫瘍内阻害機構をバイパスできる可能性がある が, 今後, 免疫誘導相だけでなく腫瘍内エフェク ター相にも適切な操作を加えることが癌の拒絶に重 要である. 米国で行われた弱毒性サルモネラ菌を静 注して腫瘍内で選択的増殖させ炎症反応を起こさせ ようとする臨床試験は, 期待された効果は認められ なかったが, 多発転移巣の環境を変えようとする一 つの試みである ${ }^{54)}$.

\section{おわりに}

メラノーマの免疫療法開発は, 基礎研究と臨床試 験の繰り返しによる理想的な translational study が 比較的うまく進んできた例であり，その成果だけで なく，この歴史から学べることは多いと思う，宿命 的な腫瘍抗原の低免疫原性, 癌細胞の heterogeneity, 様々な全身性, 局所性の抗腫瘍免疫阻害因子な ぞ，まだ多くの課題が残されているが，今後も基礎 研究成果に基づいた科学的な改良が可能であろう。 $\mathrm{T}$ 細胞反応だけでは癌治療の限界があるのは当然で
あるが, 今後, 個別化医療・集学的治療における分 子標的治療の一つのとして免疫療法が位置付けられ ることが期待される.

\section{文献}

1) Rosenberg, S. A., et al. : Prospective randomized trial of high-dose interleukin-2 alone or in conjunction with lymphokine-activated killer cells for the treatment of patients with advanced cancer. JNCI. 85 : 622-632, 1993.

2) Rubin, J. T., et al. : Immunohistochemical correlates of response to recombinant interleukin2 based immunotherapy in humans. Cancer Res. 49 : 7086-7092, 1989.

3) Topalian, S. L., et al. : Tumor-specific cytolysis by lymphocytes infiltrating human melanomas. J Immunol. 142 : 3714-3725, 1989.

4) Pockaj, B. A., et al. : Localization of Indium111-labelled tumor infiltrating lymphocytes to tumor in patients receiving adoptive immunotherapy: augmentation with cyclophosphamide in association with response. Cancer. 73 : 17311737, 1994.

5) Van der Bruggen, P., et al. : A gene encoding an antigen recognized by cytolytic $\mathrm{T}$ lymphocytes on a human melanoma. Science. 254 : 1643-1647, 1991.

6) Kawakami, Y., et al. : Shared human melanoma antigens. Recognition by tumor infiltrating lymphocytes in HLA-A2.1 transfected melanomas. J Immunol. 148 : 638-643, 1992.

7) Kawakami, Y., et al. : Cloning of the Gene Coding for a Shared Human Melanoma Antigen Recognized by Autologous $\mathrm{T}$ cells Infiltrating into Tumor. Proc Natl Acad Sci U.S.A. 91 : 3515-3519, 1994.

8) Kawakami, Y., et al. : Identification of a $\mathrm{Hu}-$ man Melanoma Antigen Recognized by Tumor Infiltrating Lymphocytes Associated with in vivo Tumor Rejection. Proc Natl Acad Sci U.S.A. 91 : 6458-6462, 1994.

9) Kawakami, Y., et al. : Identification of the immunodominant peptides of the MART-1 human melanoma antigen recognized by the majority of HLA-A2 restricted tumor infiltrating lymphocytes. J Exp Med. 180 : 347-352, 1994.

10) Kawakami, Y., et al. : Recognition of multiple epitopes in the human melanoma antigen gp100 associated with in vivo tumor regression. $J$ Im- 
munol. 154 : 3961-3968, 1995.

11) Romero, P., et al. : Antigenicity and immunogenicity of Melan-A/MART-1 derived peptides as targets for tumor reactive CTL in human melanoma. Immunol Rev. $188:$ 80, 2002.

12) Rosenberg, S. A., White, D. E. : Vitiligo in patients with melanoma: normal tissue antigens can be targets for cancer immunotherapy. J Immunother. 19 : 81-4, 1996.

13) Kawakami, Y., Rosenberg, S. A. : T-cell recognition of self antigens as tumor rejection antigens. Immunologic Res. 15 : 179-190, 1996.

14) Robbins, P. F., et al.: A mutated b-catenin gene encodes a melanoma-specific antigen recognized by tumor infiltrating lymphocytes. $J$ Exp Med. 183 : 1185-1192, 1996.

15) Kawakami, Y., et al. : Isolation of a new melanoma antigen, MART -2 , containing a mutated epitope recognized by autologous tumor-infiltrating $\mathrm{T}$ lymphocytes. J Immunol. 166 : 2871-2877, 2001.

16) Rubinfeld, B., et al. : Stabilization of beta-catenin by genetic defects in melanoma cell lines. Science. 275 : 1790-1792, 1997.

17) Wolfel, T., et al. : A p16INK4a-insensitive CDK4 mutant targeted by cytolytic T lymphocytes in a human melanoma. Science. 269 : 1281-1284, 1995.

18) Baurain, J. F., et al. : High frequency of autologous anti-melanoma CTL directed against an antigen generated by a point mutation in a new helicase gene. J Immunol. 164 : 6057-6066, 2000.

19) Kawakami, Y. : Human melanoma antigens recognized by $\mathrm{CD} 8+\mathrm{T}$ cells, in Tumor Antigens Recognized by $\mathrm{T}$ cells and Antibodies eds, Stauss, H., et al. Tumor Immunology Series. 3. Taylor \& Francis, London : 47-74, 2003.

20) Cox, A. L., et al. : Identification of a peptide recognized by five melanoma-specific human cytotoxic T cell lines. Science. $264:$ 716-719, 1994.

21) Old, L., et al. : New paths in human cancer serology. J Exp Med. 187 : 1163-1167, 1998.

22) Kiniwa, Y., et al. : Tumor antigens isolated from a patient with vitiligo and T-cell-infiltrated melanoma. Cancer Res. 61 : 7900-7907, 2001.

23) Kawakami, Y., et al. : $T$ cell responses to melanoma and melanocytes. Pigment Cell Research. 13 : 163-169, 2000.

24) Romero, P., et al. : Novel methods to monitor antigen-specific cytotoxic T-cell responses in cancer immunotherapy. Mol Med Today. 4 : 305-312, 1998.

25) Lee, P. P., et al. : Characterization of circulating $T$ cells specific for tumor-associated antigens in melanoma patients. Nat Med. 5 : 67785, 1999.

26) Parkhurst, M. R., et al. : Improved induction of melanoma reactive CTL with peptides from the melanoma antigen gp100 modified at HLAA0201 binding residues. J Immunol. 157: 2539-2548, 1996.

27) Rosenberg, S. A., et al. : Immunologic and therapeutic evaluation of a synthetic peptide vaccine for the treatment of patients with metastatic melanoma. Nat Med. $4: 321-327$, 1998.

28) Morel, S., et al. : Processing of some antigens by the standard proteasome but not by the immunoproteasome results in poor presentation by dendritic cells. Immunity. 12:107-117, 2000.

29) Cormier, J., et al. : Enhancement of cellular immunity in melanoma patients immunized with a peptide from MART-1/Melan A. Cancer J Sci Am. 3 : 37-44, 1997.

30) Rosenberg, S. Yang., et al. : Impact of cytokine administration on the generation of antitumor reactivity in patients with metastatic melanoma receiving a peptide vaccine. J Immunol. 163 : 1690-1695, 1999.

31) Clay, T. M., et al. : Changes in the fine specificity of gp100 (209-217)-reactive $T$ cells in patients following vaccinaion with a peptide modified at an HLA-A2.1 anchor residue. $J$ Immunorogy. 162 : 1749-1755, 1999.

32) Pittet, M. J., et al. : Alpha 3 domain mutants of peptide/MHC class I multimers allow the selective isolation of high avidity tumor-reactive CD8 T cells. Alpha 3 domain mutants of peptide/MHC class I multimers allow the selective isolation of high avidity tumor-reactive CD8 T cells. J Immunol. 171 : 1844-9, 2003.

33) Speiser, D. E., et al. : In vivo activation of melanoma-specific CD8 $(+) \mathrm{T}$ cells by endogenous tumor antigen and peptide vaccines. A comparison to virus-specific T cells. Eur $J$ Immunol. 32 : 731-741, 2002.

34) Coulie, P. G., et al. : A monoclonal cytolytic $\mathrm{T}$-lymphocyte response observed in a melanoma patient vaccinated with a tumor-specific anti- 
genic peptide encoded by gene MAGE-3. Proc Natl Acad Sci U.S.A. 98 : 10290-5, 2001.

35) Phan, G. Q., et al. : Immunization of patients with metastatic melanoma using both class I- and class II-restricted peptides from melanoma-associated antigens. J Immunother. 26 : 349-356, 2003.

36) Nishikawa, H., et al. : $\mathrm{CD} 4+\mathrm{CD} 25+\mathrm{T}$ cells responding to serologically defined autoantigens suppress antitumor immune responses. Proc Natl Acad Sci U.S.A. 100 : 10902-10906, 2003.

37) Nishikawa, H., et al. : Role of SEREX-defined immunogenic wild-type cellular molecules in the development of tumor-specific immunity. Proc Natl Acad Sci U.S.A. 98 : 14571-14576, 2001.

38) Shimizu, J., et al. : Induction of tumor immunity by removing $\mathrm{CD} 25+\mathrm{CD} 4+\mathrm{T}$ cells: a common basis between tumor immunity and autoimmunity. J Immunol. $163: 5211-5218$, 1999.

39) Phan, G. Q., et al. : Cancer regression and autoimmunity induced by cytotoxic $\mathrm{T}$ lymphocyte-associated antigen 4 blockade in patients with metastatic melanoma. Proc Natl Acad Sci U.S.A. 100 : 8372-8377, 2003.

40) Panelli, M. C., et al. : Phase 1 study in patients with metastatic melanoma of immunization with dendritic cells presenting epitopes derived from the melanoma- associated antigens MART-1 and gp100 [In Process Citation]. $J$ Immunother. 23 : 487-498, 2000.

41) Nestle, F., et al. : Vaccination of melanoma patients with peptide-or tumor lysate-pulsed dendritic cells. Nat Med. 4 : 328-332, 1998.

42) Banchereau, J., et al. : Immune and clinical responses in patients with metastatic melanoma to $\operatorname{cd} 34(+)$ progenitor-derived dendritic cell vaccine. Cancer Res. 61 : 6451-6458, 2001.

43) Rosenberg, S. A., et al. : Immunizing patients with metastatic melanoma using recombinant adenoviruses encoding MART-1 or gp100 melanoma antigens. J N C I. 90 : 1894-1900, 1998.

44) Rosenberg, S. A., et al. : Recombinant fowlpox viruses encoding the anchor-modified gp100 melanoma antigen can generate antitumor immune responses in patients with metastatic melanoma. Clin Cancer Res. 9 : 2973-80, 2003.

45) Rosenberg, S. A., et al. : Inability to Immunize Patients with Metastatic Melanoma Using Plasmid DNA Encoding the gp100 MelanomaMelanocyte Antigen. Hum Gene Ther. 14: 709-714, 2003.

46) Dudley, M. E., et al. : Adoptive transfer of cloned melanoma-reactive $\mathrm{T}$ lymphocytes for the treatment of patients with metastatic melanoma. J Immunother. 24 : 363-373, 2001.

47) Dudley, M. E., et al. : Cancer regression and autoimmunity in patients after clonal repopulation with antitumor lymphocytes. Science. 298 : 850-854, 2002.

48) Overwijk, W. W., et al. : Tumor regression and autoimmunity after reversal of a functionally tolerant state of self-reactive CD8 $+\mathrm{T}$ cells. $J$ Exp Med. 198 : 569-580, 2003.

49) Nagayama, H., et al. : Aberrant development of monocvyte-derived dendritic cells obtained from advanced melanoma patients: Results of phase I clinical trail of immunotherapy with tumor lysate-pulsed monocyte-derived dendritic cells plus IL2 for stage IV malignant melanoma patients. Melanoma Res. 13 : 521-530, 2003.

50) Soiffer, R., et al. : Vaccination with irradiated autologous melanoma cells engineered to secrete human granulocyte-macrophage colonystimulating factor generates potent antitumor immunity in patients with metastatic melanoma. Proc Natl Acad Sci U.S.A. 95 : 1314113146, 1998.

51) Belli, F., et al. : Vaccination with autologous tumor-derived heat-shock protein gp96 after liver resection for metastatic colorectal cancer. Clin Cancer Res. 9 : 3235-3245, 2003.

52) Triozzi, P. L., et al. : Intratumoral injection of dendritic cells derived in vitro in patients with metastatic cancer. Cancer. 89 : 2646-54, 2000.

53) Cormier, J., et al. : Heterogeneous expression of melanoma-associated antigens and HLA-A2 in metastatic melanoma in vivo. Int $J$ Cancer. 75 : 517-524, 1998.

54) Toso, J. F., et al. : Phase I study of the intravenous administration of attenuated Salmonella typhimurium to patients with metastatic melanoma. J Clin Oncol, $20: 142-$ 152, 2002. 